\title{
Curcumin Effectivity on Hepar and Reproductive Organ Recovery Male Mice (Mus musculus L) after Methoxychlor Exposure on Male Mice (Mus musculus L)
}

\author{
Mahriani, Susantin Fajariyah, \& Eva Tyas Utami \\ Biology Department. Faculty of Mathematics and Natural Science, Universitas Jember, East Java, Indonesia
}

Corresponding author: evatyas.utami@gmail.com

\begin{abstract}
Methoxychlor (MXC) is an insecticide (DDT derivates) that has the potential for bioaccumulation in mammal and causes a disruptive effect on the hepar and reproductive system. This study was done to find out the benefits of curcumin as a natural ingredient to overcome the negative impact of Methoxychlor (MXC) on hepar and male reproductive organ of Balb'C mice (Mus musculus $\mathrm{L}$ ). The study was carried out in a Completely Randomized Design (CRD) Posttest Only Control Group Design used four treatments and six replications. The curcumin treatment after administration of MXC was carried out by gavage with curcumin doses: $0.05 ; 0,1$; and $0.2 \mathrm{mg} / \mathrm{g}$ body weight, every day for two weeks, respectively. Histological observations of the liver and testis were performed using the paraffin method and Hematoxylin Eosin stained. The results showed that MXC exposure caused liver disruption by increasing the number of pycnotic necrotic hepatocytes and hydropic degeneration hepatocytes. On the male reproductive organ, MXC caused testis impairment by reducing the number of Sertoli cells and Leydig cells, spermatogenic cell counts, and the diameter of seminiferous tubules. The administration of curcumin at doses of $0.1 \mathrm{mg} / \mathrm{g} \mathrm{bw}$ in mice exposed to methoxychlor can reduce the number of hydropic degeneration hepatocytes and tend to reduce the number of pycnotic hepatocytes; and also increase the number of Sertoli cells, the number of spermatogenic cells, and the diameter of the seminiferous tubules, and tend to reduce the amount of Leydig cells. Curcumin treatment tends to recover hepar dan testis disruption of mice that were exposed by MXC.
\end{abstract}

Keyword: curcumin, methoxychlor, hepatocyte, Sertoli, Leydig, Seminiferous tubule

\section{Introduction}

Methoxychlor (MXC) is a synthetic organochlorine compound derived from DDT (Dichlorodiphenyltrichloroethane), which is widely used to control insects, including flies, cockroaches, and various types of Arthropods. This compound is classified as an insecticide that has relatively low toxicity but can leave a harmful residue to the organism (Tiemann, 2008). One of the negative impacts is a disruption in fish liver and testicular tissue (Blum et al., 2008).

MXC is metabolized by the P450 system (hepatic cytochrome P450 enzyme) through 0-demethylation and hydroxylation reactions, which produce several metabolites that are toxic and also have the potential to interfere hormones action (as Endocrine Disruptor) especially on reproductive hormones (Blizard, 2001). The disorders caused by MXC exposure include male reproductive organs atrophy, spermatogenesis impairment, and movement inhibition of spermatozoan cauda epididymis (Mathur et al., 2008). According to Okazaki et al. (2001), MXC at doses of 100 
$\mathrm{mg} / \mathrm{kg} /$ day decreases the seminal vesicles and prostate gland weight. In addition, the administration of MXC at doses of $500 \mathrm{mg} / \mathrm{kg} /$ day in mice, cause a decrease in spermatozoa movement in the cauda epididymis and a decrease in testosterone levels followed by the FSH hormone increasing. The administration of MXC at doses of 200 $\mathrm{mg} / \mathrm{kg} /$ day caused testosterone biosynthesized decreased by Leydig cells (Murono et al., 2006). Another study by Chapin et al. (1997), showed that MXC at doses $60 \mathrm{mg} / \mathrm{kg} /$ day and $150 \mathrm{mg} / \mathrm{kg} /$ day caused mice fertility decline.

Several studies have shown that MCX has toxic effects on spermatogenesis and steroidogenesis. According to Mathur et al. (2008), environmental contaminants generally impair testicular function and trigger germ cells apoptosis so that the process of spermatogenesis will be disrupted. Furthermore, Khorsandi et al. (2013), stated that the testis environment is very important to carry out spermatogenesis.

Murono et al. (2006) showed that the administration of MXC at a dose of 200 $\mathrm{mg} / \mathrm{kg} /$ day for seven days caused the seminal vesicle's weight, and testosterone biosynthesis decreased. The administration of MXC at doses of 50,100 and 200 $\mathrm{mg} / \mathrm{kg} /$ day for seven days is also induced oxidative stress and reduces levels of antioxidant enzymes in the testes and epididymis (Latchoumycandane \& Mathur, 2002). In addition, the administration of MXC at doses 50 and $150 \mathrm{mg} / \mathrm{kg} /$ day reduces spermatogenic capability, which is characterized by a decreasing number of Sertoli cells. In addition to the reproductive organs, MXC can also affect other organs such as the liver, kidneys, and nervous system. Zhou et al. (2013) showed that MXC could affect liver metabolism; however, the administration of low concentrations of MXC does not have a significant effect on the liver. Stuchal et al., (2006), states that giving $2 \mathrm{mg} / \mathrm{kg}$ MXC for six days did not cause changes in the catfish liver.

The damaging effect of MXC exposure can be reduced by curcumin treatment. Curcumin is a phytochemical component found in turmeric that is widely used as a mixture of traditional herbs for various diseases (Merinda, 2014). Besides, curcumin has a role as an anti-inflammatory, antioxidant, anticancer, antiproliferation, antidiabetic, and anticholesterol agent (Ali et al., 2006). Curcumin also has hepatoprotective activity (Agarwal \& Goel, 2016). Curcumin can inhibit the toxic effects on the liver by obstructing the secretion of TNF- $\alpha$ and IL-1 (Interleukin 1) from macrophages that induce liver necrotic (Nelson \& SidnDeletey, 2009).

Research into the hepatoprotective effect of curcumin has been carried out by Otuchere et al. (2014), which showed that administration of curcumin at a dose of $50 \mathrm{mg} / \mathrm{kg} / \mathrm{BW}$ together with propanil at a dose of $20 \mathrm{mg} / \mathrm{kg} \mathrm{BW}$ intragastrically three times a week for 28 days in rats was able to inhibit increased lipid peroxidase levels and normalize GSH (Glutathione Sulfhydril) levels. Curcumin treatment has a protective effect on reproductive organs (Mohebbati et al., 2017). In addition, curcumin in Curcuma longa can protect germ cells from apoptosis in dexamethasone-induced mice (Khorsandi et al., 2013). 
According to Shu et al., (2009), curcumin can inhibit proliferation and induce apoptosis in HSC (Hepatic Stellate Cell) in vitro. Curcumin can increase the expression of Bcl-2, which is known to play a role in the inhibition of apoptosis in HepG2 liver cells (Elmansi et al., 2017). Research into the protective effect of curcumin on male reproductive organs by Ogutzurk et al. (2012) showed that administration of curcumin at a dose of $1 \mathrm{mg} / \mathrm{kb}$ BW could increase motility and concentration of spermatozoa in the epididymis of rats exposed to Cadmium. Giving curcumin in female mice for 42 days at a dose of $100 \mathrm{mg} / \mathrm{kg}$ BW after being induced with D-galactose can increase the number of follicles at various stages of development (Yan et al., 2018).

Several studies have shown that the effect of Curcuma longa affects genital, testicular, and ovarian glands. Curcuma longa can also provide anti-inflammatory, anticancer, and anti-apoptotic properties (Farombi et al., 2007; Cort et al., 2012; Akta et al., 2012). Besides, Mohebbati et al. (2017) state that Curcuma longa can increase antiapoptotic factors and decrease apoptotic agents. Research by Khorsandi et al. (2013) stated that the curcumin content in Curcuma longa could protect germ cells from apoptosis in dexamethasone-induced mice.

Turmeric extract has an antioxidant effect on Swiss male mice that are treated with arsenic, which is indicated by the inhibition of SA (sodium arsenite). SA induces glucose increased. Provision of turmeric aid in regulating blood glucose levels (Karim et al., 2010). Turmeric extract reactivates p53, increase p21 and cyclin D1, regulate abnormal cell cycles, and reduce the expression of HBx (Hepatitis B) by accelerating its degradation (Kim et al., 2011). P53 is a gene that can induce HBx degradation (Park et al., 2009). Curcumin is also one of the compounds in turmeric that plays a role in protecting and providing a therapeutic effect on the liver disease through cellular and molecular mechanisms. Curcumin suppresses pro-inflammatory cytokines, lipid peroxidase results, P13K/Akt, and activation of liver cells against oxidative stress. In addition, curcumin can also reduce the toxic effects on the liver by inhibiting the secretion of TNF- $\alpha$ and IL-1 (Interleukin 1) from macrophages that play a role in inducing necrotic in the liver (Nelson \& Sidney, 2009). According to Shu et al., (2009), curcumin inhibit proliferation and induce apoptosis in HSC (Hepatic Stellate Cell) in vitro. Curcumin increases the expression of Bcl-2, which inhibits apoptosis in HepG2 cells or liver cancer cells (Elmansi et al., 2017). Increased Bcl-2 decreased caspase-3 and caspase-9 activity, which causes inhibition of apoptosis (Wilson and Potten, 2000).

Based on the potential of curcumin as a hepatoprotection, it is necessary to conduct research on the effects of curcumin on liver damage recovery and its potential to restore testicular damage due to MXC exposure. Curcumin is expected to be able to repair the liver and testicular histological damage in mice that have been exposed by MXC. 


\section{Material and Method}

\subsection{Animal Preparation}

The study was conducted using eight weeks of male Balb'C mice (Mus musculus L.), 20-23 g weight. Mice were obtained from Pusvetma Surabaya, acclimatized for one week before being treated.

\subsection{Research Design}

The study was conducted with a Completely Randomized Design (CRD) Posttest Only Control Group Design with five treatments (K-, K +, D1, D2, and D3), each with six replications.

\subsection{Curcumin Extraction}

The source of curcumin for this research came from turmeric flour extract. Turmeric flour used was obtained from the Surabaya Jember store. $300 \mathrm{~g}$ of powder was macerated with $70 \%$ alcohol for two days. The maceration results are filtered then the solution is evaporated using a rotary evaporator until a crude extract is obtained.

\subsection{MXC and Curcumin Treatment}

The MXC treatment $(0.42 \mathrm{mg} / \mathrm{g} \mathrm{BW})$ was carried out intraperitoneally at two-day intervals, for 36 days. The MXC dose given refers to the study of Vaithanathan et al. (2008) that showed that $150 \mathrm{mg} / \mathrm{kg}$ BW of MXC reduced the spermatogenic process. MXC is given to groups $\mathrm{K}+, \mathrm{P} 1, \mathrm{P} 2$, and $\mathrm{P} 3$. $\mathrm{K}$ - group without MXC treatment, $\mathrm{K}+$ group is given by MXC without curcumin. Curcumin treatment in the form of turmeric flour extract was given to groups $\mathrm{P} 1, \mathrm{P} 2$, and $\mathrm{P} 3$ after the administration of MXC was done by gavage at a dose of $0.05 ; 0.1$; and $0.2 \mathrm{mg} / \mathrm{g}$ BW, every day for two weeks. During the treatment, the mice were fed by BR 511 (PT Charoen Phokpand Indonesia) and drinking tap water ad libitum.

\subsection{Hepar and Testis Histological Preparation}

On the last day of administration of curcumin, mice were sacrificed, and the right lobe liver and right testicles were removed to be made histological preparations using the paraffin method and Hematoxylin-Eosin staining. The preparation process begins with fixation of the liver and testes using 10\% PBS formalin, dehydration using alcohol gradually, clearing using xylol, paraffin infiltration, embedding, sticking to the holder and $6 \mu$ slicing using a rotary microtome. The paraffin ribbon is placed on the object-glass, which has been smeared with albumin-glycerin previously. The next process is the staining of Hematoxylin-Eosin, preceded by deparaffinization using xylol, immersion in alcohols gradually ranging from absolute alcohol to distilled water, then being put into Hematoxylin staining for 3-5 seconds. The next step is the immersion in alcohol levels ranging from $30 \%$ to $70 \%$ alcohol, then put in Eosin staining for 7-10 minutes, followed by immersion in $80 \%$ alcohol to absolute, xylol, and then drops Stellan for covering preparations using a cover glass. 


\subsection{Hepar and Testis Parameters}

Liver and testicular histology observations were carried out on six slides, representing six mice that were used as replication so that histological observations were made on 36 slides. From each of these slides, three microscope fields of view were observed so that a total of 108 fields of view were taken. In the liver observation, the number of liver cells (hepatocytes) damaged (hydropic degeneration and pycnotic necrotic) is calculated in the central venous region. Hydropic degenerated hepatocytes showed swollen cells, vacuole cytoplasm, squeezed nuclei at the edge of cells (Hadisusanto et al., 2016). Hepatocytes undergoing pycnotic necrotic are characterized by smaller/larger than normal cell sizes, blackened hepatocyte color, and the fragmentation of the nucleus (Fajariyah et al., 2010). In the testicular observations carried out observations of seminiferous tubules, which were round slices. Observation of testicular histology, including the number of Sertoli cells, the number of Leydig cells, as well as the number of Spermatogenic cells, and also the measurement of the thickness of the seminiferous tubular epithelium. Analysis of seminiferous tubules epithelium thickness is done by measuring the difference between the outer diameter and inner diameter of the seminiferous tubules, which are round slices. The data were analyzed by one-way ANOVA and followed by the Duncan Multiple Range Test (DMRT) with a 99\% confidence level.

\section{Result and Discussion}

The results of the calculation of the average number of hepatocytes undergoing hydropic degeneration can be seen in Table 1. The results of One Way ANOVA analysis showed that the treatment of curcumin has a very significant effect on the average of hepatocytes undergoing hydropic degeneration. The results of the Duncan test showed that the average number of hepatocytes undergoing hydropic degeneration in the positive control group was very significantly different from the negative controls. This is because methoxychlor is toxic, and at a dose of $0.42 \mathrm{mg} / \mathrm{g}$ BW for 36 days causes damage to the structure of liver histology.

Hydropic degeneration is an early step of hepatocyte degenerative. The mechanism of hydropic degeneration in cells is caused by plasma membrane alteration, especially interference with ion regulation and water volume due to the loss of ATP. This disruption causes more water flow into the cell because the active transport mechanism of $\mathrm{Na}+$ and $\mathrm{K}+$ ions is disturbed so that vacuoles formed in the cytoplasm; as a result, the cell swell and the cell nucleus will be pushed to the edge (Fajariyah et al., 2010). 
Table 1. Average number of hepatocytes undergoing hydropic degeneration after administration of curcumin in mice exposed to MXC

\begin{tabular}{|c|c|}
\hline $\begin{array}{l}\text { Curcumin treatment }(\mathrm{mg} / \mathrm{g} \\
\text { BW) }\end{array}$ & $\begin{array}{l}\text { The average number of hydropic } \\
\text { degeneration hepatocytes }(X \pm S D)\end{array}$ \\
\hline K- (without MXC) & $120,33^{a} \pm 6,47$ \\
\hline $\mathrm{K}+($ with curcumine $)$ & $277,17^{d} \pm 9,35$ \\
\hline 0,05 & $225,3^{c} \pm 19,76$ \\
\hline 0,1 & $181,00^{\mathrm{b}} \pm 9,88$ \\
\hline 0,2 & $160,67 \mathrm{~b} \pm 19,76$ \\
\hline
\end{tabular}

Note: Numbers followed by different letters in the same column show very significant differences between treatment doses $(\mathrm{p}<0.01)$.

Furthermore, the DMRT test results showed that the average number of hepatocytes undergoing hydropic degeneration in the positive control group was very significantly different from the treatment group at doses of $0.05,0.1$, and $0.2 \mathrm{mg} / \mathrm{g}$ BW. The average number of hepatocytes undergoing hydropic degeneration decreased in all treatment groups that are treated by curcumin compared with positive controls. The increase in curcumin dose is accompanied by a decrease of hepatocytes hydropic degeneration. This is presumably because the administration of curcumin after MXC exposure can prevent hydropic degeneration hepatocyte. Hydropic degeneration is the first degree of damage to the liver, with vacuoles that contain water in the cytoplasm instead of fat or glycogen. These changes are generally a result of metabolic disorders. Hydropic degeneration is reversible, but if this process occurred continuously, there would damage to the cell membrane and changes in the nucleus. Hence, the cells looked fatty as a result of irreversible degeneration to the necrotic stage (Utomo et al., 2012). Normal hepatocytes and hydropic degeneration hepatocytes can be seen in Figure 1.
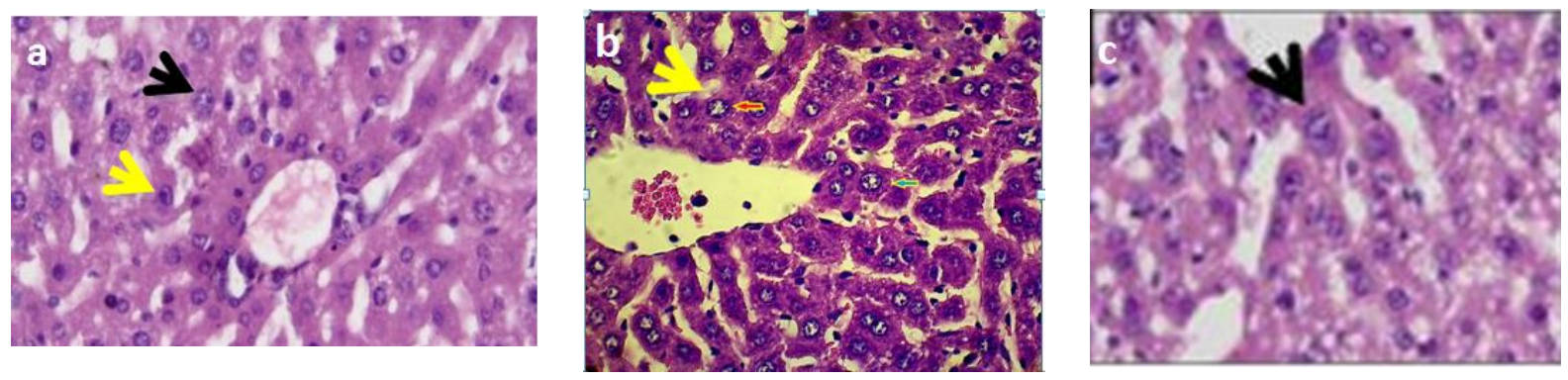

Figure 1. Normal hepatocytes (yellow arrows) and hydropic degeneration hepatocytes in controls (black arrows) (a), hepatocytes in the positive control (b) and administration of curcumin dose of $0.2 \mathrm{mg} / \mathrm{g}$ BW (c) 
The results of the average number of hepatocytes undergoing pycnotic necrotic can be seen in Table 2. The results of One Way ANOVA analysis showed that the treatment of curcumin has a very significant effect on the average number of hepatocyte necrotic pycnotic. DMRT test results showed that the average number of hepatocyte necrotic pycnotic in the positive control group was very significantly different from the negative control. This is presumably because MXC compounds can affect liver metabolism (Zhou et al., 1995) caused an increase in the number of pycnotic hepatocytes. Furthermore, the DMRT test results also showed that the average number of necrotic pycnotic hepatocytes in the positive control group did not differ very significantly with the treatment group doses of $0.05,0.1$, and $0.2 \mathrm{mg} / \mathrm{g}$ g BW. However, the average number of pycnotic necrotic hepatocytes in all treatment groups decreased compared with positive controls. The average number of degenerative hydropic and pycnotic-necrotic hepatocytes shown in Figure 2.

Table 2. The average number of hepatocytes in pycnotic necrotic after administration of curcumin in mice exposed to MXC.

\begin{tabular}{ll}
\hline \multicolumn{1}{c}{ Curkumin Treatment (mg/g bw) } & $\begin{array}{c}\text { The average number of hepatocytes } \\
\text { necrotic-picnotic (x } \pm \text { SD) }\end{array}$ \\
\hline K-(without MXC) & $75,83^{\mathrm{a}} \pm 15,63$ \\
K+(with kurkumin) & $120,50^{\mathrm{b}} \pm 6,29$ \\
0,05 & $116,00^{\mathrm{b}} \pm 13,49$ \\
0,1 & $109,17^{\mathrm{b}} \pm 19,77$ \\
0,2 & $105,67^{\mathrm{b}} \pm 12,93$ \\
\hline
\end{tabular}

Note: Numbers followed by different letters in the same column show very significant differences between treatment doses $(\mathrm{p}<0.01)$.

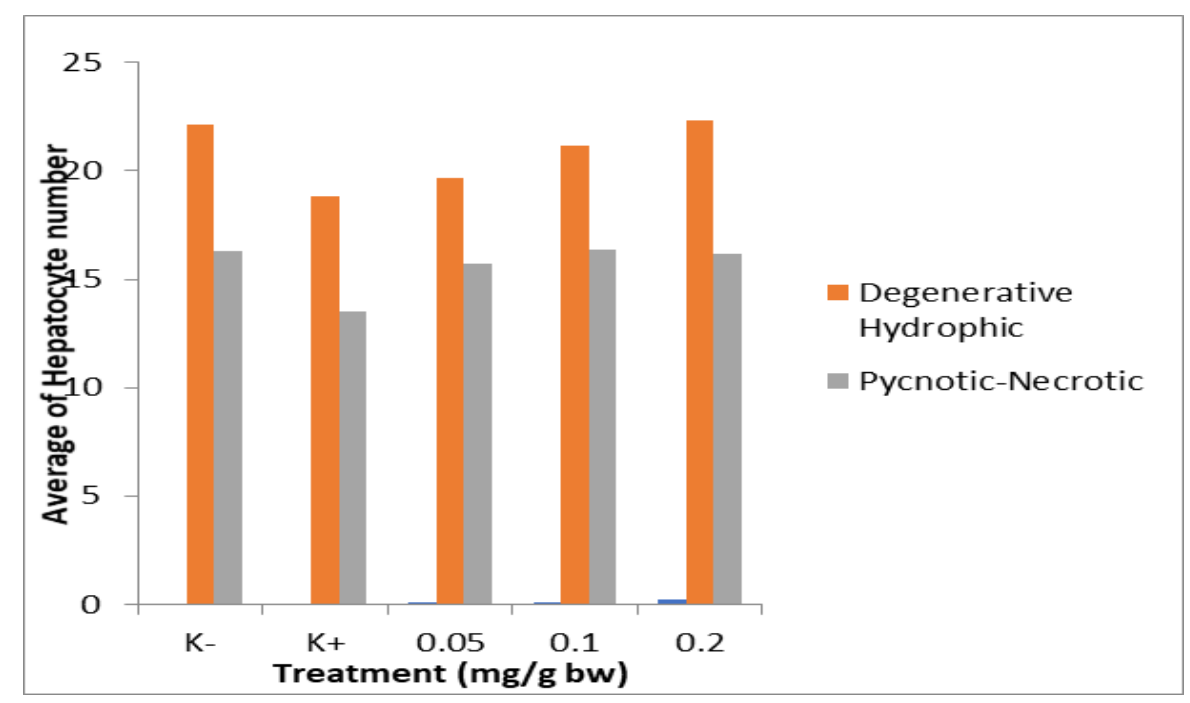

Figure 2. The average number of degenerative hydropic and pycnotic-necrotic hepatocytes 
The results of calculating the average number of Sertoli cells and Leydig cells can be seen in Table 3 and also shown in Figure 3. The results of One Way ANOVA analysis showed that the treatment of curcumin has a very significant effect on the average number of Sertoli cells and Leydig cells.

Table 3. The average number of Sertoli cells and Leydig cells after curcumin administration in mice exposed to MXC

\begin{tabular}{ccc}
\hline $\begin{array}{c}\text { Treatment } \\
\mathbf{m g} / \mathbf{g} \text { bw }\end{array}$ & Sertoli & Average ( $\mathbf{x} \pm \mathbf{S D}$ ) \\
\cline { 2 - 3 } & & Leydig \\
\hline K-(without MXC) & $22,12^{\mathrm{a}} \pm 0,36$ & $16,31^{\mathrm{a}} \pm 3,13$ \\
$\mathrm{~K}+($ with kurkumin) & $18,83^{\mathrm{b}} \pm 1,17$ & $13,54^{\mathrm{a}} \pm 1,19$ \\
0,05 & $19,69^{\mathrm{b}} \pm 0,37$ & $15,69^{\mathrm{a}} \pm 1,42$ \\
0,1 & $21,13^{\mathrm{a}} \pm 1,04$ & $16,36^{\mathrm{a}} \pm 2,50$ \\
0,2 & $22,32^{\mathrm{a}} \pm 1,10$ & $16,14^{\mathrm{a}} \pm 0,79$
\end{tabular}

Note: Numbers followed by different letters in the same column show very significant differences between treatment doses $(\mathrm{p}<0.01)$.

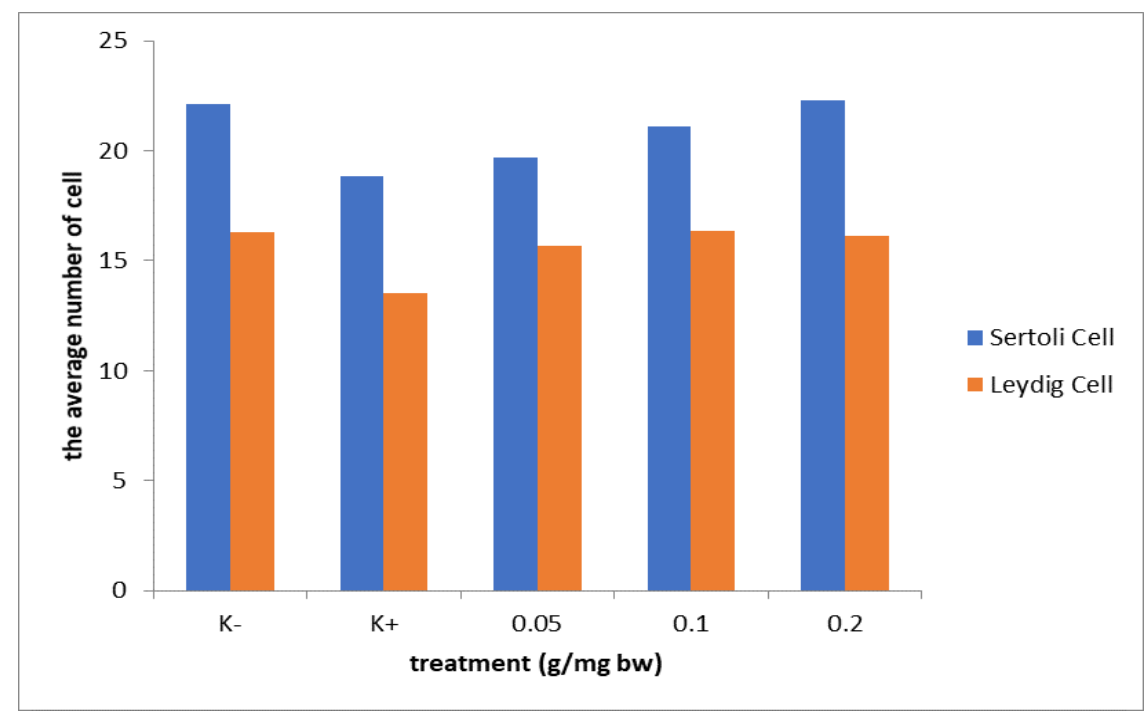

Figure 3. The average number of Sertoli and Leydig Cell

DMRT test results showed that the average number of Sertoli cells in the positive control group was very significantly different from the negative control, whereas the average number of Leydig cells in the positive control was not significantly different from the negative control, but tended to decrease the amount of Leydig cells. This is presumably because the MXC compound can induce the occurrence of oxidative stress caused by increased hydrogen peroxide and lipid peroxidation in testes (Latchoumycandane \& Mathur, 2002). MXC can also cause free radicals enhancement in 
the mitochondria of the central nervous system (Schuh et al., 2009), so that toxic to the reproductive organs and CNS central nervous system (Gore, 2002). Central nervous system damage due to free radicals can inhibit the secretion of GnRH thereby reducing FSH (follicle-stimulating hormone) and LH (Luteinizing Hormone). The reduction in FSH and LH affects Sertoli cell proliferation and inhibits steroidogenesis function in the differentiation and maturation of Leydig cells (Akingbemi et al., 2000). Sertoli cells and Leydig cells can be seen in Figure 3.

DMRT test results showed that the average number of Sertoli cells in the positive control group was very significantly different from the treatment group doses of 0.1 and $0.2 \mathrm{mg} / \mathrm{g}$ BW. The average number of Sertoli cells in the curcumin group increased to coincide with increased doses compared with positive controls. In contrast, the average number of Leydig cells in the positive control group did not differ significantly, with the group doses of $0.05,0.1$, and $0.2 \mathrm{mg} / \mathrm{g}$ BW. However, curcumin administration tends to increase the number of Leydig cells. This is presumably because curcumin has a therapeutic effect on the male reproductive system through antioxi\&t and anti-inflammatory effects, so it is expected that the administration of curcumin can increase the number of Sertoli and Leydig cells. This is supported by Giannessi et al., (2008) research that the administration of $80 \mathrm{mg} / \mathrm{kg}$ curcumin reduced Leydig cell necrotic. It is said that curcumin has more significant than vitamin $\mathrm{E}$ to capture free radicals so that it can protect the brain from lipid peroxide disorders (Agarwal \& Goel, 2016). Sertoli and Leydig Cells can be seen in Figure 4.
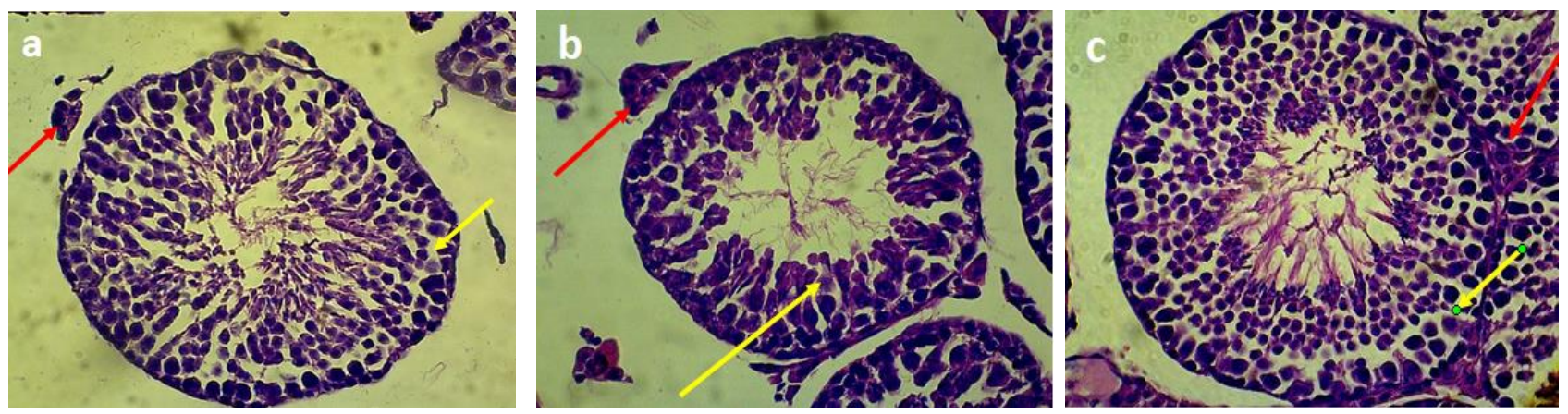

Figure 4. Sertoli cells (yellow arrows) and Leydig cells (red arrows) on the testicular cross-section of the negative control (a), positive control (b), and treatment $0.2 \mathrm{mg} / \mathrm{g}$ BW (c). 400x magnification.

The results of the average number of spermatogenic cells can be seen in Table 4. The results of One Way ANOVA analysis showed that the treatment of curcumin has a very significant effect on the average number of spermatogenic cells. These average numbers can also be seen in Figure 5. 
Table 4. The average number of spermatogenic cells after administration of curcumin in mice exposed to MXC.

\begin{tabular}{lcc}
\hline \multirow{2}{*}{$\begin{array}{c}\text { Treatment } \\
\text { (mg/g bw) }\end{array}$} & Spermatogonium & Average (x \pm SD) \\
\cline { 2 - 3 } K-(without MXC) & $24,26^{\mathrm{a}} \pm 2,7$ & Spermatosit Primer \\
K+(without kurkumin) & $19,15^{\mathrm{b}} \pm 1,26$ & $32,42^{\mathrm{a}} \pm 1,05$ \\
0,05 & $19,32^{\mathrm{b}} \pm 0,58$ & $27,72^{\mathrm{b}} \pm 0,67$ \\
0,1 & $20,69^{\mathrm{ab}} \pm 4,1$ & $31,69^{\mathrm{ab}} \pm 2,45$ \\
0,2 & $22,48^{\mathrm{ab}} \pm 1,12$ & $32,33^{\mathrm{a}} \pm 5,14$ \\
\hline
\end{tabular}

Note: Numbers followed by different letters in the same column show very significant differences between treatment doses $(\mathrm{p}<0.01)$.

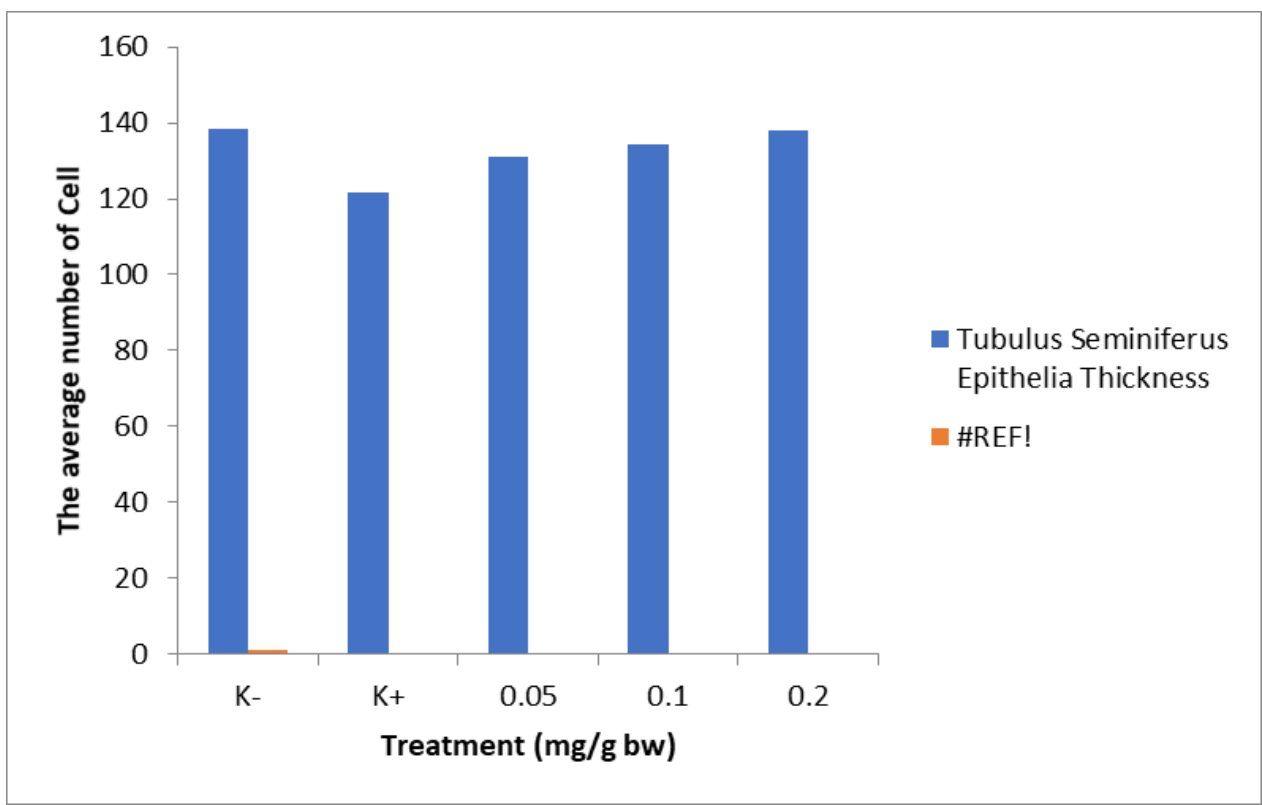

Figure 5. The average number of spermatogonium and primary spermatocyte.

DMRT test results showed that the average number of spermatogenic cells (spermatogonium and primary spermatocytes) in the positive control group decreased very significantly compared to the negative control group. This is presumed because the MXC compound can induce oxidative stress in the form of increased hydrogen peroxide and lipid peroxidation in the testes (Latchoumycandane \& Mathur, 2002). As a spermatogenesis site, the testes are very vulnerable to the oxidation process by free radicals that interfere with spermatogenesis and spermatozoa membranes. It was stated that oxidative stress caused by increased free radicals cause a decrease in the number of spermatogenic cells (Tremellen, 2008). 
DMRT test results showed that the average number of spermatogenic cells in the positive control group did not differ significantly with the treatment group doses of $0.05,0.1$, and $0.2 \mathrm{mg} / \mathrm{g}$ BW. However, the average number of spermatogenic treatment groups increased parallel with increasing doses. The higher dose of curcumin administration tends to increase the number of spermatogenic cells. This is thought to be caused because curcumin has great potential to capture free radicals (Agarwal \& Goel, 2016) due to the administration of MXC. Therefore the treatment of curcumin will be able to obtain free radicals and increase the number of spermatogenic cells that are decreased due to MCX treatment.

The results of calculating the average thickness of seminiferous tubules can be seen in Table 5 and Figure 6. The results of One Way ANOVA analysis showed that the treatment of curcumin has a very significant effect on the average thickness of seminiferous tubules epithelium.

Table 5. Average thickness of seminiferous tubular epithelium after administration of curcumin in mice exposed to MXC.

\begin{tabular}{lc}
\hline \multicolumn{1}{c}{ Treatment } & $\begin{array}{c}\text { The average of the seminiferous tubular epithelium } \\
(\boldsymbol{\mu m})(\mathbf{x} \pm \mathbf{S D})\end{array}$ \\
\hline K-(tanpa MXC) & $138,47^{\mathrm{a}} \pm 0.81$ \\
$\mathrm{~K}+($ tanpa kurkumin) & $121,6^{\mathrm{b}} \pm 4.57$ \\
$0,05 \mathrm{mg} / \mathrm{g} \mathrm{bw}$ & $131,18^{\mathrm{c}} \pm 0.58$ \\
$0,1 \mathrm{mg} / \mathrm{g} \mathrm{bw}$ & $134,26^{\mathrm{c}} \pm 0.18$ \\
$0,2 \mathrm{mg} / \mathrm{g} \mathrm{bw}$ & $138,13^{\mathrm{a}} \pm 0.34$
\end{tabular}

Note: Numbers followed by different letters in the same column show very significant differences between treatment doses $(\mathrm{p}<0.01)$.

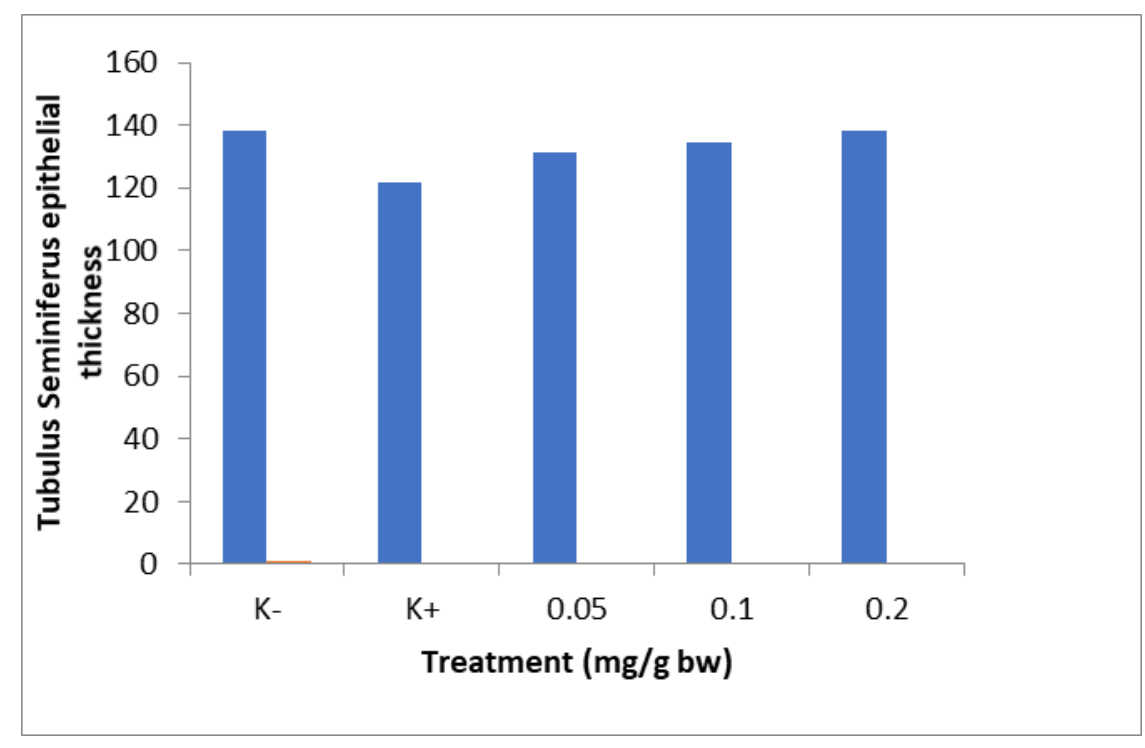

Figure 6. Tubulous seminiferous epithelial thickness 

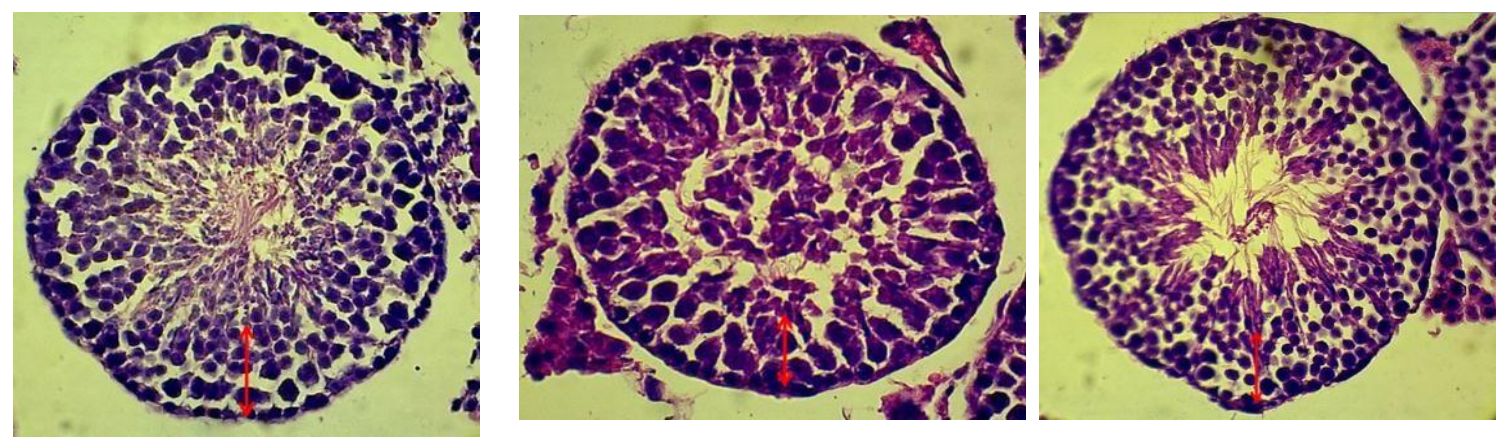

Figure 7. The thickness of the seminiferous tubules epithelial (red lines) in the negative control (a), positive control (b), and administration of curcumin dose of $0.2 \mathrm{mg} / \mathrm{g} \mathrm{BW}(\mathrm{c})$

Figure 7 shown that curcumin at $0.2 \mathrm{mg} / \mathrm{g}$ BW increases the thickness of tubulous seminiferous epithelia compared with positive control. DMRT test results showed that the thickness of the seminiferous tubule epithelium in the positive control group was lower and significantly different from the negative control; this was because the MXC compound induces oxidative stress. It was further stated that the decreased thickness of the seminiferous tubular epithelium was also thought to be caused by a decrease in testosterone levels (Latchoumycandane \& Mathur, 2002).

DMRT test results showed that the average thickness of the seminiferous tubules in the positive control group was lower and significantly different from the treatment group at a dose of $0.05,0.1$, and $0.2 \mathrm{mg} / \mathrm{g}$ BW. The higher dosage of curcumin tends to increase the thickness of the seminiferous tubule epithelium. This is presumably because curcumin has the potential to capture free radicals greater than vitamin $\mathrm{E}$ (Agarwal \& Goel, 2016). Therefore, curcumin can act as an antioxi\&t to prevent oxidative stress. Oxidative stress can cause a decrease in the number of spermatogenic cells (Tremellen, 2008). Consequently, curcumin as an antioxidant can avoid a reduction in the number of spermatogenic cells, which means that curcumin can prevent a reduction in the thickness of the epithelium of the seminiferous tubules. It was stated that the number of spermatogenic cells and Sertoli cells affected the thickness of the seminiferous tubular epithelium (Cupp et al., 2003). Curcumin can also prevent oxidation of free radicals that damage cells; hence curcumin can prevent testicular histological changes. It was mentioned by Ilbey et al. (2009), that curcumin can prevent the depletion of the seminiferous epithelial layer and the infection of fibrous connective tissue into the perivascular tissue due to cisplatin induction.

\section{Conclusion}

It can be concluded that the administration of turmeric extract containing curcumin can improve liver and testicular histological damage of mice after methoxychlor exposure. The administration of turmeric extract in mice exposed to methoxychlor can reduce the number of hydropic degeneration hepatocytes and tend to 
decrease the number of hepatocyte pycnotic and can increase the number of Sertoli cells, Leydig cells, spermatogenic cells, and thickness seminiferous tubule epithelium. The increasing dose given provides a better recovery effect.

\section{Reference}

Agarwal, S., \& Goel R. K. (2016). Curcumin and Its Protective and Therapeutic Uses. Nat. J. Physical. Pharm. Pharmacol, 6(1), 1-8. http://doi.org/ 10.5455/njppp.2016. 6.3005201596

Aktas, C., Kanter. M., Erboga. M. \& Ozturk, S. (2012). Anti-apoptotic effects of curcumin on cadmium-induced apoptosis in rat testes. Toxicol Indust Health, 28, 122-130. https://doi.org/10.1177/0748233711407242

Akingbemi, BT., Ge, Ren-Shan., Klinefelter, GR., Gunsalus, GL., \& Hardy, M. P. (2000). A Metabolite of Methoxychlor, 2,2-Bis(p-Hydroxyphenyl)-1,1,1-Trichloroethane, Reduces Testosterone Biosynthesis in Rat Leydig Cells Through Suppression of Steady-State Messenger Ribonucleic Acid Levels of the Cholesterol Side-Chain Cleavage Enzyme. Biology of Reproduction, 62(3), 571-578. https://doi.org/ 10.1095/biolreprod62.3.571

Ali, B. H., Marrif, H., Noureldayen, Bakhiet, A. O., \& Blunden, G. (2006). Some Biological Properties of Curcumin: a Review. Natural Product Communications (NPC), 1(6), 509-521. https://doi.org/10.1177/1934578X0600100613

Blum, J. L., Nyagode, B. A, James, M. D, \& Denslow, N. D. (2008). Effects of the Pesticide Methoxychlor on Gene Expression in the Liver and Testes of the Male Largemouth Bass (Micropteus salmoides). Aquat Toxicol, 86(4), 456-469. https://doi.org/ 10.1016/j.aquatox.2007.12.008

Chapin, R. E., Harris, H. W., Davis, B. J., Ward, S. M., Wilson, R. E., Maurey, M. A., Lockhart, A. C., Smialowicz, R. J., Moser, V. C., Burka, L. T., \& Collins, B. J. (1997). The Effects of Perinatal/Juvenile Methoxychlor Exposure on Adult Rat Nervous, Immune, and Reproductive System Function. Fundam Appl Toxicol, 40, 138-157. https://doi.org/10.1006/faat.1997.2381

Cort, A., Timur, M., Ozdemir, E., Kucuksayan, E., \& Ozben, T. (2012). Synergistic Anticancer Activity of Curcumin and Bleomycin: an In Vitro Study using Human Malignant Testicular Germ Cells. Mol Med Rep, 5(6), 1481-1146. https://doi.org/10.3892/mmr.2012.848

Cupp, A. S., Uzumcu, M., Suzuki, H., Dirks, K., Phillips, B., \& Skinner, M. K. (2003). Effect of Transient Embryonic In Vivo Exposure to the Endocrine Disruptor Methoxychlor on Embryonic and Postnatal Testis Development. Journal of Andrology, 24(5), 736745. https://doi.org/10.1002/j.1939-4640.2003.tb02736.x 
Elmansi, A. M., El-Karef, A. A., El-Shistawy, M. M., \& Elsa, L. A. (2017). Hepatoprotective Effect of Curcumin on Hepatocellular Carsinoma Trough Autophagic and Apoptosis Pathway, Anals of Hepatology, 16(4), 607-618. https://doi.org/10.5604/01.3001.0010.0307

Fajariyah, S., Utami, E, T., \& Arisandi, Y. (2010). Efek Pemberian Estrogen SIntetik (Diethylstilbestrol) terhadap Struktur Hepar \& Kadar SGOT \& SGPT pada Mencit (Mus musculus L) Strain Balb’C. Jurnal Ilmu Dasar, 11(1), 76-82.

Farombi, E. O., Abarikwu, S. O., Adedara, I. A., \& Oyeyemi, M. O. (2007). Curcumin and Kolaviron Ameliorate Di-n-butylphthalate-induced Testicular Damage in Rats, Basic Clin Pharmacol Toxicol. 100(1), 43-48. https://doi.org/10.1111/j.17427843.2007.00005.x

Farzaei, M. H., Zobeiri, M., Parvisi, F., El-Sendury, F. F., Marmouzi I., Coy-Barrera, E., Naseri, R., Nabawi, S. M., Rahimi, K., \& Abdollahi, M. (2018). Curcumin in Liver Diseases: A Systematic Review of The Cellular Mechanism of Oxidative Stress and Clinical Perspective, Nutrients. 10(7), 855. https://doi.org/10.3390/nu10070855

Giannessi, F., Giambelluca, M. A., Grasso, L., Scavuzzo, M. C., \& Ruffoli, R. (2008). Curcumin protects Leydig cells of mice from damage induced by chronic alcohol administration. Medical science monitor: international medical journal of experimental and clinical research,14(11), 237-242. http://europepmc.org/ abstract/med/18971866

Gore, A, C. (2002). Organochlorine Pesticides Directly Regulate Gonadotropin-releasing Hormone Gene Expression and Biosynthesis in The GT1-7 Hypothalamic Cell Line. Molecular and Cellular Endocrinology, 192 (1-2), 157-170. https://doi.org/ 10.1016/S0303-7207(02)00010-2

Ilbey, Y. O., Ozbek, E., Cekmen, M., Simsek, A., Otunctemur, A., \& Somay, A. (2009). Protective Effect of Curcumin in Cisplatin-induced Oxidative Injury in Rat Testis: Mitogen-Activated Protein Kinase and Nuclear Factor-kappa B Signaling Pathways. Hum Reprod, 24(17), 1717-1725. https://doi.org/10.1093/ humrep/dep058

Karim, R., Haque, A., Islam, K., Ali, N., Salam, K, A., Saud, Z, A., Hossain, E., Fajol, A., Akhand. A, A, Himeno, S., \& Khaled, Hossain. (2010). Protective Effect of dietary Suplementation of Turmeric (Curcuma longa L.) on Sodium Arsenit Induced Biochemical Perturbation in Mice, Bangladesh Med Res Counc Bull. 36 (3), 82-88. https://doi.org/10.3329/bmrcb.v36i3.7287

Khorsandi, L., Mirhoseini, M., Mohamadpour, M., Orazizadeh, M., \& Khaghani, S. (2013). Effect of Curcumin on Dexamethasone-Induced Testicular Toxicity in Mice. Pharmaceutical M Biology, 51(2), 206-212. https://doi.org/10.3109/ 13880209.2012.716854 
Kim. J., Ha, Hye-lin., Moon, Hyung-Bae., Lee, Yeon-weol., Cho, Chong-kwan., Yoo, Hwaseung., \& Yu, Dae-yeul. (2010). Chemopreventive Effect of Curcuma longa Linn on Liver Pathology in HBx Transgenic Mice, Integrative Cancer Therapies. 10(2), 1-10. https://doi.org/10.1177/1534735410380613

Blizard, D., Sueyoshi, T., Negishi, M., Dehal, S. S., \& Kupfer, D. (2001). Mechanism of induction of cytochrome p450 enzymes by the proestrogenic endocrine disruptor pesticide-methoxychlor: interactions of methoxychlor metabolites with the constitutive androstane receptor system. Drug metabolism and disposition: the biological fate of chemicals, 29(6), 781-785. https://pubmed.ncbi.nlm.nih.gov/ $11353743 /$

Latchoumycandane, C., \& Mathur, P. P. (2002). Induction of Oxidative Stress in The Rat Testis After Short-term Exposure to The Organochlorine Pesticide Methoxychlor. Arch. Toxicol, 76, 692-698. https://doi.org/10.1007/s00204-002-0388-9

Mathur, P. P, Saradha, B., \& Vaithinathan, S. 2008. Impact of Environmental Toxicants on Testicular Function. Immun Endoc Metab Agents Med Chem, 8(1), 79-90. https://doi.org/10.2174/187152208783790705

Merinda, F. M., 2014. Hepatoprotective Effect of Curcumin in Chronic Hepatitis. J.Majority, 3(7), 52-56. https://juke.kedokteran.unila.ac.id/index.php/majority/ article/view/477

Mohebbati, R., Anaeigodari, A., \& Khazdair, M. R. (2017). The Effect of Curcuma longa and Curcumin in Reproductive System. Endocrine Regulations, 51(4), 220-228. https://doi.org/10.1515/enr-2017-0024

Murono, E. P., Derk, R. C., \& Akgul, Y. (2006). In Vivo Exposure of Young Adult Male Rats to Methoxychlor Reduces Serum Testosterone Levels and Ex Vivo Leydig Cell Testosterone Formation and Cholesterol Sidechain Cleavage Activity. Reprod Toxicol. 21(2), 148-153. https://doi.org/10.1016/j.reprotox.2005.08.005

Ogutzurk, H., Ciftci, O., Aydin, M., Timurkaan, N., Beytur, A., \& Yilma, F. (2012). Amelioratif Effects of Curcumin Against Acute Cadmium Toxicity on Male Reproductive in Rat. Andrologia. 44(4), 243-249. https://doi.org/10.1111/j.14390272.2012.01273.x

Okazaki, K., Okazaki, S., Nishimura, S., Nakamura, H., Kitamura, Y., Hatayama, K., Nakamura, A., Tsuda, T., Katsumata, T., Nishikawa, A., \& Hirose, M. (2001). A repeated 28-day oral dose toxicity study of methoxychlor in rats, based on the 'enhanced OECD test guideline 407' for screening endocrine-disrupting chemicals. Archives of toxicology, 75(9), 513-521. https://doi.org/10.1007/ s002040100273 
Park, S. G., Min, J. Y., Chung, C., Hsich, A., \& Jung, G. (2009). Tumor Suppressor Protein p53 Induced Degradation of Oncogenic Protein HBx. Cancer Lett, 282(2), 229-237. https://doi.org/10.1016/j.canlet.2009.03.019

Schuh, R. A., Richardson, J. R., Gupta, R. K., Flaws, J. A., \& Fiskum, G. (2009). Effects of The Organochlorine Pesticide Methoxychlor on Dopamine Metabolites and Transporters in The Mouse Brain. Neurotoxicology, 30(2), 274-280. https://doi.org/10.1016/j.neuro.2008.12.015

Shu, J. C., He, Y. J., Lv, X., Zhao, J. R., Zhao, J., Shen, Y., Ye, G. R., \& Wang, L. X. (2009). Effect of Curcumin on The Proliferation and Apoptosis of Hepatic Stellate Cell. Brazilian Journal of Medical and Biological Research, 42(12), 1173-1178. https://doi.org/ 10.1590/S0100-879X2009005000041

Stuchal, L. D., Kleinov, K. M., Stageman, J. J., \& James, M. O. (2006). Demethylation of The Pesticide Methoxychlor in Liver and Intestine From Untreated, Methoxychlor Treated, and 3 Methylcolanthrene Treated Channel Catfish (Ictalurus punctatus): Evidence For Roles of CYP1 and CYP3A Family Isozyme. Drug Metabolism and Disposition, 34(6), 932-938. https://doi.org/10.1124/dmd.105.009068

Tiemann, U. (2008). In Vivo and In Vitro Effects of The Organochlorine Pesticides DDT, TCPM, Methoxyxhlore, and Lindane on The Female Reproductive Tract of Mammals: A Review. J.Reproductive Toxicology, 25(3), 316-326. https://doi.org/10.1016/j.reprotox.2008.03.002

Tremellen, K. (2008). Oxidative Stress and Male Infertility-A Clinical Perspective. Human Reproduction Update, 14 (3): 243-258. https://doi.org/10.1093/ humupd/dmn004

Utomo, Y., Hidayat, A, Dafip, M., \& Sasi, F, A. (2012). Studi Histopatologi Hati Mencit (Mus musculus L) yang Diinduksi Pemanis Buatan. Jurnal MIPA, 35 (2), 122-129. https://journal.unnes.ac.id/nju/index.php/JM/article/view/2604

Saradha, B., Vaithinathan, S., \& Mathur, P, P. (2008). Single Exposure to Low Dose of Lindane Causes Transient Decrease in Testicular Steroidogenesis in Adult Male Wistar Rats. Toxicology. 244 (2-3), 190-197. https://doi.org/10.1016/ j.tox.2007.11.011

Wilson, J, W., \& Potten, C, S. (2000). The Effect of Exogenous Prostaglandin Administration on Tumour Size and Yield in Min/+ mice. Cancer Research.60: 4645-4653. https://cancerres.aacrjournals.org/content/60/16/4645.full

Yan, Zhengjjie, Dai, Youjin., Fu, Heling., Zheng, Yuan., Bao, Dan., Yin, Yuan., Chen, Qin., Nie, Xisowei., Hao, Qingting., Hou, Daorong., \& Cui, Yugui. (2018). Curcumin Exert a Protective Effect Against Premature Ovarian Failure in Mice. Journal of Molecular Endocrinology, 60(3), 261-271. https://doi.org/10.1530/JME-17-0214 
Zhou, C., Zhao, Xiao-Meng., Li, Xiao-Feng., Wang, Cheng., Zhang, Xiao-Ting., Liu, Xi-Zhi., Ding, Xiao-Feng., Xiang, Shuamg-Lin, \& Zhang, J. (2013). Curcumin Inhibits AP- $2 \gamma$ induced Apoptosis in The Human Malignant Testicular Germ Cells In Vitro. Acta Pharmacol Sin. 34(9), 1192-1200. https://doi.org/10.1530/JME-17-0214. 